\title{
Regulating the Regulators through Codes of Corporate Governance for Public Institutions in Nigeria: Using INEC as a Case Study
}

\author{
Akin Olawale Oluwadayisi, Ph.D..$^{*} \quad$ Olaposi Adedolapo Olaseeni, $\mathrm{PhD}^{2}$ \\ Moruf Oluwakayode Mimiko, LL.M, MPhil. ${ }^{3}$ \\ 1.Faculty of Law, Adekunle Ajasin University, Akungba-Akoko, Ondo-State, Nigeria \\ 2. Faculty of Law, Obafemi Awolowo University, lle-Ife, Osun State, Nigeria \\ 3. Faculty of Law, Adekunle Ajasin University, Akungba-Akoko, Ondo-State, Nigeria
}

\begin{abstract}
In Nigeria, there exists numerous policies, laws and regulations regulating one aspect of the society, economy or polity. Among them are the laws establishing INEC as the umpire body over the conduct, supervision and collation of electoral process. Beside these core roles, INEC is the regulator over political parties and their activities in Nigeria but the question this article asks is that who regulates INEC itself? A similar question also applies to other public regulators such Corporate Affairs Commission, Human Rights Commission, Securities and Exchange Commission, Central Bank of Nigeria, Economic and Financial Crime Commission and many others that exists within the legal system in Nigeria? Alternatively, should we leave these statutory public regulators to operate and regulate other artificial persons under them without questioning some of their policies even when they are anti-public or anti-people or non-compliant? The article adopts the doctrinal legal research methodology to argue the need to regulate the regulators who are governmental agencies otherwise known as public regulators in Nigeria and indeed, in all nations in order to ensure sanity in the system and avoid a situation where a regulator appears to be above the law. It first examines the constitutional and statutory duties of INEC being the agency in perspective. It argues that the basis for the supposed regulation of these regulators should be the basic principles of corporate governance such as: responsibility, accountability, financial transparency/auditing, stakeholders' participation, ethnical standard and sustainability in the affairs of the nation's electoral governance. The article concludes that there is possibility of non-compliance with statutory mandates by most regulators in Nigeria without being checkmated and until codes are put in place to regulate them, one can say that the country is being ill-governed. It also posits that in the absence of this desired codes on the Commission especially during the periods of transition, electioneering, campaign and voting, any acclaimed free and fair election is a deception and hypocrisy to the confessed electoral values and extant laws. The article therefore recommends that a Unit known as Corporate Governance Monitoring Unit be established in all regulatory agencies to ensure compliance with the ideals of corporate governance. It further suggests inclusion of neutral (non-political) experts in the governing board of INEC and/or management of election process, who will first be trained before discharging their duties rather than those who are co-opted on a temporary basis each time election is to be conducted to act as collation and returning officers.
\end{abstract}

Keywords: Regulating, Regulators, Corporate, Governance, Electoral, Process, INEC.

DOI: $10.7176 / \mathrm{DCS} / 11-7-05$

Publication date:July $31^{\text {st }} 2021$

\section{Introduction}

Initially, the Code of Corporate Governance were drafted to apply to the business enterprises such as companies listed on the main board of the Stock Exchange, public companies, Banks, other financial Institutions, and insurance entities and may be private companies rendering financial services. ${ }^{1}$ In Nigeria, all public companies are expected to adopt the Code of Corporate Governance (CCG). ${ }^{2}$ The Code is a set of principles and does not purport to determine the detailed course of conduct of directors on any particular matter. It provides that the board structure develops greater interaction among all members when dealing with matters such as strategy, planning, performance, resources, standards of conduct and communication with stakeholders. ${ }^{3}$

Coincidentally, in 2018, Financial Reporting Council of Nigeria (FRCN), by virtue of its enabling law, ${ }^{4}$ unveiled the draft of the Nigerian Code of Corporate Governance (NCCG). The NCCG are to institutionalize the highest standards of corporate governance best practices in Nigerian companies (particularly those not already covered by sectoral regulations), promoting public awareness of essential corporate values and ethical practices to enhance market integrity, and rebuilding public confidence in the Nigerian economy. ${ }^{5}$ The NCCG also seeks to facilitate trade and contribute to the ease of doing business in Nigeria. Unfortunately, because of criticisms that were directed at its predecessor, the suspended 2016 Code, the NCCG 2018 is not made applicable to Incorporated Trustees, not-for profit entities and private companies generally. An earlier attempt by the FRC to include a Private Sector Code (PSC) in its National Corporate Governance Code was challenged and defeated in 
court. In the case of Eko Hotels Limited v. Financial Reporting Council of Nigeria,${ }^{6}$ Justice O.E. Abang held that the FRCN's power, as stated in its enabling Act, covers only public interest entities. Thus, the NCCG 2018 is applicable and required to be implemented by organisation which are: public companies (whether listed or not); all private companies which are holding companies of public companies or other regulated entities; concession and/or privatized companies and; regulated private companies.

However, in most developed and many developing countries now, the principles of corporate governance are now applicable by adaptation not only by private companies but also public corporations and institutions like INEC. This is being done to ensure public accountability and corporate responsibility. For instance, in South African, the King IV Report on Code of Corporate Governance 2016 now require public institutions such as Universities and Commissions to imbibe the principles of corporate governance. ${ }^{7}$ The rationale behind the incorporation which this article underscores are that, if the regulating agencies are, themselves not regulated, they cannot have the first-hand experience of the workability of the codes. They will also likely commit similar errors that the CCG is meant to prevent or correct, hence, there is no justification for possible sanctions by such regulating body where they themselves violates the same principle.

\section{Statutory and Constitutional Powers and Functions of INEC}

Assessing a body like INEC in its operations and performances, the first yardstick will be the statutes upon which it is established. Virtually all electoral bodies are constitutional institutions. The Constitution provides for the powers and functions of INEC as follows which include power to: ${ }^{8}$

(a) organise, undertake and supervise all elections to the offices of the President and Vice-President, the Governor and Deputy Governor of a State, and to the membership of the Senate, the House of Representatives and the House of Assembly of each State of the Federation;

(b) register political parties in accordance with the provisions of the Constitution and an Act of the National Assembly;

(c) monitor the organisation and operation of the political parties, including their finances;

(d) arrange for the annual examination and auditing of funds and accounts of political parties, and publish a report on such examination and audit for public information;

(e) arrange and conduct the registration of persons qualified to vote and prepare, maintain and revise the register of voters for the purpose of any election under this Constitution;

(f) monitor political campaigns and provide rules and regulations which shall govern political parties;

(g) ensure that all Electoral Commissioners, Electoral and Returning Officers take and subscribe to the oath of office prescribed by law.

(h) delegate any of its powers to any Resident Electoral Commissioner and;

(i) carry out such other functions as may be conferred upon it by an Act of the National Assembly.

In addition to the above functions, section 2 of the Electoral Act 2010 (E.A) (as amended) further confers powers on the INEC to conduct voter and civic education, promote knowledge of sound democratic election processes and conduct any referendum required to be conducted pursuant to the provisions of the 1999 Constitution or any other Law or Act of the National Assembly. ${ }^{9}$ Although, The Constitution does not make provision for the role of INEC the conduct of elections into the Local Government Councils ${ }^{10}$ the current amendment has introduced certain compliance with the E.A. 2010. ${ }^{11}$ These duties are central to ensuring constitutional democracy. It is salient, sacrosanct and fundamental to the sustenance of the Constitution itself. Considering the nature and interest that exists variously in politics, INEC being the umpire, would have to resist all temptations and possibility of being drawn into the political battlefield as a supporter of one political party of the other particularly the party in power. It may have to bear insults and false insinuations against it by politicians with dignity, a duty to observe the law and to do justice. ${ }^{12}$

The rational for creating an independent body such as INEC is clear. It is a special extra-ministerial constitutional body saddled to handle elections in such a manner that the body becomes insulated in the conduct of free and fair election devoid of influence of political partisanship and governmental interference. It is likely that the electoral process will be prone to being marred if handled by conventional departments of the government. Hence, the reason why the E.A. vests in INEC like other statutory organisations the status of a corporate and identity with all its powers and privileges to sue and be sued as well as to exists perpetually. ${ }^{13}$

\section{Corporate Governance Responsibility and Professional Ethics of INEC and Its Officials in Electoral Process}

The Manual for Election Officials for the 2015 elections sets out clearly what may be considered the mission 
statement or the goals as well as the ethical conduct expected of INEC and its officials in the electoral process. It sets out the right attitude and conduct of election officials as pre-requisites to the building of a strong democratic institution that will work for the benefit of all citizens. It guides well-trained election officials to ensure that all eligible and duly registered and accredited voters freely cast their ballots and that the results arising from such elections accurately reflect the wishes of the electorates.

\subsection{Corporate Responsibilities}

Corporate responsibility is taking ownership of a role, duty and liability that comes with it. The credibility of an election which confers legitimacy on the election makes it acceptable to all. However, it is a function of responsibility discharged on who it is conferred. The Commission takes responsibility to ensure the legitimacy of the processes for which it is established. The corporate governance principle on responsibility posits that every official from all levels in the administration of election process will understand the content of their duties and take it with all sense of responsibility. In other words, election officials must recognize and understand that the successful administration of the election process is founded on the basic fundamental guiding principles of independence, impartiality, integrity and transparency.

There must be no gap in the chain of responsibility from the governing board, management, permanent officials and engaged ad-hoc staff, hence, the process fail and the intended result which is a seamless democratisation process is thrown in shambles. According to the South African Codes of Corporate Governance 2016, the responsibility of the Board of any organisation including a statutory body like INEC is encapsulated in the following: ${ }^{14}$

i. that members constituting the governing body and management should assume collective responsibility for steering and setting the direction of the organisation; approving policy and planning; overseeing and monitoring of implementation and execution by management; and ensuring accountability for organizational performance.

ii. that members constituting the governing body and management should exercise courage in taking risks and capturing opportunities, but do so in a responsible manner and in the best interests of the organisation.

iii. hat members constituting the governing body and management should take responsibility for anticipating, preventing or otherwise ameliorating the negative outcomes of the organisation's activities and outputs on the triple context in which it operates, and the capitals that it uses and affects.

iv. hat members constituting the governing body and management should attend meetings of the governing body and its committees, and devote sufficient time and effort to prepare for those meetings.

It is important to mention here that the Constitution does not and it is not expected to be the document that will define the responsibilities of the Board. Although, the composition and powers of the INEC like other bodies established by the Constitution are as contained in Part 1 of the Third Schedule to this Constitution, ${ }^{15}$ there is no specific definition of the roles and responsibilities of the Chairman of INEC and other key officials on the body. How then can we assess performance whether they are in compliance or not?

\subsection{Corporate Ethics}

Another significant principle of corporate governance that should guide the corporate institutions like INEC is a set of standard ethical codes relevant to the conduct of election and its administration. These set of ethical codes and are essential to ensure both the appearance and actual integrity of the electoral process are in order. They can be tagged the guiding principles or ethical framework for election officials conducting elections.

If the elections must be credible and their outcome acceptable, election officials in the discharge of their duties must be transparent and neutral, exhibit a high level of integrity, be credible, courageous and dedicated, respect the secrecy of the vote and conduct their duties according to the Constitution of the Federal Republic of Nigeria 1999, the E.A. 2010 (as amended) and INEC Guidelines. To this end, each official is subjected to affirming the oath of neutrality. ${ }^{16}$ This oath/affirmation of neutrality binds election officials to the legal and ethical standards intended to guide their activities during the entire Electoral Process. All Election Officials must adhere to these standards and implement them with common sense and in good faith. The Independent National Electoral Commission (INEC) will sanction Election Officials for violation of the Oath/Affirmation of Neutrality.

Section 29 of the E.A. provides that all staff appointed by the Commission taking part in the conduct of an election shall affirm or swear before the High Court an oath of neutrality as in the second schedule to this Act. The content and purpose of this is to ensure compliance with ethical standard that is core to the integrity of the body as an umpire. Hence, all electoral officers, presiding officers, and returning officers and all staff appointed by the Commission taking part in the conduct of an election shall affirm or swear an oath of loyalty and neutrality indicating that they would not accept bribe or gratification from any person, and shall perform their functions and duties impartially and in the interest of the federal Republic of Nigeria without fear or favour. 


\subsection{Public Accountability and Transparency}

Another set of codes and principles of CCG are public accountability and transparency. Going by the minimum standards of Financial Reporting Council of Nigeria (FRCN), 2016 for non-for-profit organisations which public institutions should fall within, accountability involves preparing in accordance with approved framework of accounting and financial reporting the accounts of the organisation. ${ }^{17}$ The accounting standard in this case shall be determined, from time to time, by the Financial Reporting Council of Nigeria. ${ }^{18}$ Audited annual financial statements are expected to be distributed to relevant stakeholders. In this case, the stakeholders ought to include the organs of government, political parties and the members of the public. This happened after the audit and risk management Committee has reviewed them and the Governing Board has approved them. The Chief Financial Officer of the regulator is held responsible for preparing annual and other periodic financial statements. ${ }^{19}$

However, the Governing Board of the regulator should ensure complete inventory of all the assets of the organization, both non-current assets and current assets wherever they may be situate, while also ensuring as far as possible both the possession and legal ownership. ${ }^{20}$ The assets of the regulator may donated to or acquired by the organization in order to benefit the public good and are normally intended towards that use alone.

Under the E.A. 2010 (as amended), the Secretary is saddled with the responsibility for keeping of proper records of the proceedings of the commission as well as all member or staff on the INEC under him..$^{21}$ This suggests that the accountability task about records keeping and financial account is not only that of a particular but all depending on the particular item involved, the office involved and tasks. The Secretary will only take responsibility for coordination, control and administration of the staff as expected. ${ }^{22}$

To further ensure the regulators are regulated, the CCG introduced a whistle blowing policy and practice by which each regulator would be more pressured to ensure compliance with accountability principle knowing fully well that there are persons who will be rewarded for exposing any illegal act. It states that the board of every regulator should establish a whistle-blower policy that encourages individuals to report credible information on illegal practices or violations of policies of the organization, specifies that the organization will protect the individual from retaliation, and identifies the parties to whom such information can be reported. ${ }^{23}$

Unfortunately, the 2016 code which was meant for organisations under part $\mathrm{C}$ of Companies and Allied Matter Act, ${ }^{24}$ came under serious and vicious attack by many Incorporated Trustees particularly the religious organisations. Meanwhile, by now, advocacy on adaptation of the Not-for-Profit Organisations Governance Code 2016 should have reached statutory and constitutional regulators like INEC. It is also doubtful if any of the regulatory agencies in Nigeria has developed a similar code for internal operation, effectiveness and their efficiency. This is the part of the issue about the regulatory agencies today. They rather regulate but they are not regulated and as such, the FRCN still has to take the bull by the horn to develop a set of CCG for the Public Sector State Owned Regulators such as INEC. Developing Codes of Corporate Governance for Public Sector and State-owned Regulators like INEC will certainly promote responsibility, accountability, work ethics and integrity needed to discharge her constitutional and statutory tasks as well as delivery credible election.

\section{INEC and Credible Electoral Process}

As was earlier stated in the introduction to this article, the electoral process is one of the hallmarks of democracy in any modern or civilised society. Therefore, once the people lose confidence in the process, democracy itself loses its value.

From the provisions of the 1999 Constitution, the Electoral Act 2010 (as amended) and the INEC Manual for the 2015 general elections, it will appear that integrity is key to the delivery of a credible election. The statutory and regulatory framework already spell out this fact. ${ }^{25}$ Therefore the goal and mission of the Commission would be to ensure elections credible and legitimate. When this is done, it is easy for the outcome of the election to be acceptable to the electorates. ${ }^{26}$ The question that follows the herculean task and responsibility is how would INEC live up to her constitutional obligations?

The solution is partly found in the basic codes on integrity that CCG envisages for all public institution that are regulators. INEC should therefore and first of all, internally regulate itself before projecting to the public. In doing this, members of the governing body and staff should individually and collectively cultivate integrity as a character and exhibit them in their conduct of all elections. The governing body must act in good faith and in the best interests of the electorates rather than the political party that is in power. It is equally important that they avoid conflicts of interest. In cases where a conflict cannot be avoided, it should be disclosed to the public and recusation can be done at the earliest opportunity, and then proactively managed as determined by the codes of corporate governance that is put in place subject to legal provisions. The argument here is that since free and fair election is the target of both the Commission and the electorates, integrity is part of the ladder to climb to achieve it. The perception of whether or not an election is credible is a determinant of the attitude exhibited by those empowered to handle the process which the electorates want to see and assess. 


\section{Conclusion}

The article submits that if the system encourages private and public companies to engage the principles of Corporate Governance in the internal administration of their private businesses, then, there is no reason why public institutions such as Independent National Electoral Commission (INEC) should not adopt a module of CGCG for its running and that of political parties it superintends over. And paramount among these principles are: ethnical standard, sustainability, responsibility, accountability, financial transparency/auditing and stakeholders participation in the affairs of the nation's electoral governance.

It concluded that the absence of this desired regulation on the polity of Nigeria especially during periods of transition, electioneering, campaign and voting is a deception and hypocrisy to confessed electoral value and compliance to extant laws.

The article therefore recommends that a unit known as corporate governance Monitoring Unit be established in all parastatals to ensure compliance with the ideals of corporate governance by each regulator in Nigeria. My recommendations include but not limited to the making of code of corporate governance for public institutions, stakeholders' participation and appointment of neutral experts (non-political) in the running of public institutions in Nigerian for better performance and delivery that benefits the citizens. In addition, the Electoral Act should include the responsibilities of key officials of INEC particularly the Chairman which is absent. Again, it suggests that in line with the spirit and fundamentals of the CCG in many developed and developing countries today, there should be inclusion of neutral (non-political) experts in the governing board and/or management of the Institution such as from experts from academic (like Vice Chancellors) rather than those who are co-opted on a temporary basis each time election is to be conducted.

\section{References/Endnotes}

${ }^{1}$ OECD, OCDE “The OECD Principles of Corporate Governance” (2004) Contaduría y Administración, 216.

2 See Adegbite, Emmanuel, "Corporate Governance Regulation in Nigeria” (2012) Corporate Governance: The International Journal of Business in Society, 1.

${ }^{3}$ Financial Reporting Council of Nigeria Act, 2011, s.11(c) and s.51(c).

${ }^{4}$ ibid.

${ }^{5}$ See 'National Code of Corporate Governance 2018: Learning from the 2016 Controversies', BlackwoodStone, available at www.blackwoodstone.com accessed 23rd June 2021.

${ }^{6}$ (Unreported: Suit No. FHC/L/CS/1430/2012 delivered on 21/03/2014).

${ }^{7}$ See South African, the King IV Report on Code of Corporate Governance 2016, para 6.6

${ }^{8}$ Constitution of Federal Republic of Nigeria (CFRN) 1999 (as amended), s.153 (1) and para F 15 of Part 1 of the Third Schedule.

${ }^{9}$ E.A. 2010 (as amended), s.2(a)-(c).

10 Item 22 of the Exclusive Legislative List of the 1999 Constitution expressly excludes election into a local government council or any office in such council

${ }^{11}$ Electoral Act 2010 (as amended), No. 6 2017, s. 152A-152D.

${ }^{12}$ Offornze D. Amucheazi \& Chudi Onwuasoanya, The Judiciary, Politics and Constitutional Democracy in Nigeria (1999-2007) (Snaap Press, Enugu, 2008) 78

${ }^{13}$ E.A. 2010 (as amended), s.2(a)-(c).

${ }^{14}$ South African, the King IV Report on Code of Corporate Governance 2016, Principle 1, part 5.

${ }^{15}$ CFRN 1999 (as amended), s.153(2).

${ }^{16}$ Manual for Election Officials for the 2015, p.7.

${ }^{17}$ Not for Profit Organisations: Governance Code 2016, para D 25.1

${ }^{18}$ Ibid

${ }^{19}$ Not for Profit Organisations: Governance Code 2016, para 25.3.

${ }^{20}$ Not for Profit Organisations: Governance Code 2016, para 26.1.

${ }^{21}$ E.A. 2010 (as amended), s.8(2)(a).

22 E.A. 2010 (as amended), s.8(3)-(4).

${ }^{23}$ Not for Profit Organisations: Governance Code 2016, para 29.1

${ }^{24}$ Cap. C20 LFN 2004 now Part F of CAMA 2020.

${ }^{25}$ Professional Ethics of Election Officials 2010, para 1.3.

26 Ibid. 